\title{
Arena metacaolínica. Material prometedor como adición al cemento Portland
}

\author{
Metakaolin sand - a promising addition \\ for Portland cement
}

\author{
I. Janotka(*), F. Puertas ${ }^{(* *)}$, M. Palacios ${ }^{(* *)}$, C. Varga ${ }^{(* *)}$, L. Krajči(***)
}

Recepción/Received: 20-III-09

Aceptación/Accepted: 25-IX-09

Publicado online/Online publishing: 1-VI-10

RESUMEN

Las reservas de arena caolínica de la cantera eslovaca de Vyšný Petrovec ascienden a un total de 20 millones de toneladas. El material metacaolínico, que resulta al calentar la arena caolínica a $650{ }^{\circ} \mathrm{C}$, contiene entre un 31,5 y un $40 \%$ de metacaolinita, además de ilita, moscovita, cuarzo y feldespato. El objetivo de este estudio ha sido comprobar que esa arena calcinada es un material puzolánico; así como caracterizar los cementos y morteros preparados con dicha arena (MK-1). La hidratación de las mezclas se evaluó mediante calorimetría de conducción, y difracción de rayos $X(D R X)$ y Análisis térmico-diferencial y termogravimétrico (ATD-TG). Se ha evaluado el desarrollo resistente de las mezclas y morteros; así como su estructura porosa. Los resultados obtenidos han demostrado que esa arena metacolínica (MK-1) es un material puzolánico y que podría utilizarse como adición al cemento y en la preparación de morteros.

Palabras clave: cemento, mortero, arena metacaolínica, actividad puzolánica, hidratación.

\section{SUMMARY}

The kaolin sand resource at the Vyšný Petrovec quarry in Slovakia comes to a total of 20 megatonnes. The metakaolin material obtained by heating kaolin sand at $650{ }^{\circ} \mathrm{C}$ contains from 31.5 to $40 \%$ (wt) metakaolinite, as well as illite, muscovite, quartz and feldspar. The aim of this study was to verify whether this calcined sand (MK1) is a pozzolanic material and characterize the cements and mortars prepared with it. The hydration reactions taking place in the blends were assessed with conduction calorimetry, X-ray diffraction (XRD) and differential thermal analysis-thermogravimetry (DTA-TG). Blend and mortar strength development and pore structure were also evaluated. The results obtained showed that this metakaolin sand (MK-1) is a pozzolanic material apt for use as a cement addition and for making mortars.

Keywords: cement, mortar, metakaolin sand, pozzolanic activity, hydration.

(*) Building Testing and Research Institute (Bratislava, Slovak Republic).

(**) Instituto de Ciencias de la Construcción Eduardo Torroja, CSIC (Madrid, España).

(***) Slovak Academy of Sciences (Bratislava, Slovac Republic). 


\section{INTRODUCCIÓN}

Según Kraus (1), los principales criterios geológicos y económicos para evaluar las prestaciones de las materias primas no metálicas eslovacas son la calidad, la presencia de impurezas perjudiciales, la disponibilidad, su adecuación para un uso industrial concreto y un mercado potencial. El resultado de la evaluación (2) de la cantera de caolín de Vyšný Petrovec es el siguiente: materia prima de baja calidad, contenido de caolinita de entre el 20 y el $40 \%$, composición mineralógica muy variable (requiere una explotación selectiva), ningún uso industrial conocido y escasa explotación ( $y$, en cualquier caso, destinada únicamente al mercado nacional). Se calcula que la cantera cuenta con algo más de veinte millones de toneladas de arena caolínica, que no puede utilizarse como materia prima en el sector de la cerámica y el vidrio, ni siquiera tras ser sometida a tratamientos de laboratorio. Un estudio inicial llevado a cabo con este material pobre en caolín (3-4) ha demostrado que la arena caolínica original se transforma completamente en arena metacaolínica (MK) si se calienta durante una hora a $650{ }^{\circ} \mathrm{C}$. En dicho estudio, el cemento Portland (PC) se sustituyó por un 20 , un 30 y un $40 \%$ de arena MK. El contenido en metacaolinita de estas mezclas de PC con arena MK oscilaba entre el 4,10 y el $14,48 \%$. A mayor contenido de metacaolinita, menor era la proporción de $\mathrm{Ca}(\mathrm{OH})_{2}$ en la mezcla PC-MK. Los valores de la resistencia a la compresión tras el curado de 90 días en estos morteros variaron entre 81,2 y $93,5 \mathrm{MPa}$, siendo este valor de 53,5 MPa en el caso del PC de referencia.

Los resultados de este estudio concuerdan con los expuestos en un estudio previo realizado por autores griegos (5), en el que se comparó el efecto en la hidratación del cemento de cuatro metacaolines con un contenido de metacaolín de entre el 38 y el $52 \%$ con el efecto de un metacaolín comercial muy puro. Al utilizar metacaolines griegos como sustitutos del árido fino, el hormigón resultante mostraba una resistencia mayor que el $\mathrm{PC}$, a todas las edades hasta los 90 días. En general, se constató el efecto positivo de la sustitución del PC por metacaolín en la resistencia del hormigón a los dos días de curado. El metacaolín utilizado se caracterizó por su contenido en materiales puzolánicos muy reactivos, que generaron un hormigón de buenas prestaciones. Se han publicado múltiples artículos de investigación sobre el uso potencial del metacaolín como sustituto del cemento en el hormigón. No obstante, el conocimiento actual se centra en el comportamiento puzolánico del metacaolín comercial muy puro y sus efectos en la hidratación del cemento, la estructura porosa, la resistencia y otras propiedades importantes (6-11).

En la presente investigación se estudia la reactividad de la arena calcinada (su potencial puzolanicidad) y el comportamiento de sistemas de cemento Portland y arena

\section{INTRODUCTION}

According to Kraus (1), the major economic and geological criteria for judging the performance of Slovakian non-metallic raw materials include quality, presence of detrimental impurities, availability, suitability for a specific industrial use and potential market. The Vyšný Petrovec kaolin quarry has been assessed (2) as follows: low quality raw material, kaolinite content of 20 to $40 \%$ (wt), highly variable mineralogical composition (calling for selective mining), no known industrial use, scantly mined (for the domestic market only, if at all). The quarry is calculated to have slightly over twenty megatonnes of kaolin sand, which is unusable as a raw material for the ceramic and glass industry, even after laboratory treatment. An initial study conducted on this kaolin-poor material (3-4) showed that the original kaolin sand transforms completely into metakaolin sand (MK) after heating for 1 hour at $650^{\circ} \mathrm{C}$. In that study, Portland cement (PC) was replaced with 20, 30 and $40 \%$ (wt) of MK sand. The metakaolinite content in these PC-MK sand blends varied from 4.10 to $14.48 \%$ (wt). The higher the metakaolinite content, the lower was the proportion of $\mathrm{Ca}(\mathrm{OH})_{2}$ in the PC-MK. The 90-day compressive strength in these mortars ranged from 81.2 to 93.5 $\mathrm{MPa}$, compared to a value of $53.5 \mathrm{MPa}$ for the reference $P C$.

The findings were consistent with the results reported in a prior paper by Greek authors (5). The effect of four metakaolins with a metakaolin content of from 38 to $52 \%$ (wt) on cement hydration was compared to the effect of very pure commercial metakaolin. When the Greek metakaolins were used to replace the fine aggregate, the resulting concrete exhibited higher strength than OPC at all ages up to 90 days. When metakaolin was used to replace $P C$, its beneficial effect on concrete strength generally appeared after 2 days. The metakaolin used was characterized by its content in highly reactive pozzolanic materials that yielded high performance concrete. Many papers have reported on research into the potential use of metakaolin as a cement replacement in concrete. Current knowledge, however, focuses on the pozzolanic behaviour of very pure commercial metakaolin and its effects on cement hydration, pore structure, strength and other important properties (6 -11).

The present study addresses the reactivity of the calcined sand (its potential pozzolanicity) and behaviour in Portland cement - metakaolin sand (PCMK) systems. 
metacaolínica (PCMK). La hidratación y evolución de las mezclas y morteros PCMK se evaluó en función del calor de hidratación, de las resistencias mecánicas y de la estructura porosa de los materiales finales.

\section{PARTE EXPERIMENTAL}

\subsection{Materiales}

Como materiales para el estudio se seleccionaron: un cemento Portland CEM I 42.5 R suministrado por Holcim Rohožník (Eslovaquia) y arena metacaolínica (MK-1), que se preparó mediante el tratamiento térmico de la misma, extraída del yacimiento eslovaco de Vyšný Petrovec, durante una hora a $650{ }^{\circ} \mathrm{C}$. El PC se mezcló con MK-1 en proporciones de $90 \%$ / $10 \%$, $80 \%$ / $20 \%$ y $60 \%$ / $40 \%$ (en peso) para las mezclas de PCMK-1 y de $95 \% / 5 \%$ y $90 \%$ / $10 \%$ en el caso de los morteros PCMK-1. También se fabricaron una pasta y un mortero de PC de referencia (100\% de PC).

La arena MK-1 que se ha utilizado tenía un contenido en metacaolinita del $36 \%$ en peso. En el caso de las mezclas PCMK-1, el contenido en metacaolinita osciló entre el 3,6 y el $14,4 \%$ en peso, y entre el 5 y el $10 \%$ en los morteros elaborados con PC y arena MK-1. En las Tablas 1-3 se detallan la composición del cemento Portland y las propiedades y características físicas del PC y las mezclas PCMK-1 secas, así como las resistencias características del cemento (EN 196-1).
Hydration and variations in these PCMK blends and mortars are assessed on the basis of heat of hydration, mechanical strength, pore structure and end materials.

\section{EXPERIMENTAL}

\subsection{Materials}

The materials chosen for the study were CEM I $42.5 R$ Portland cement supplied by Holcim Rohožník (Slovakia) and metakaolin sand (MK-1) prepared by heating kaolin sand mined at the Vyšný Petrovec deposit in Slovakia for 1 -hour at $650{ }^{\circ} \mathrm{C}$. The $P C$ was mixed with $M K-1$ in proportions by weight of $90 \%$ / 10\%, 80\% / 20\% and $60 \%$ / $40 \%$ for PCMK-1 blends and 95\% / 5\% and $90 \%$ / $10 \%$ for making PCMK-1 mortars. A reference $P C$ paste and mortar (100\% PC, wt) were also prepared.

The MK-1 sand used had a metakaolinite content of $36 \%$ (wt). The metakaolinite content in the PCMK-1 blends ranged from $3.6-14.4 \%$ (wt) and from 5 to $10 \%$ (wt) in mortars containing PC and MK-1 sand. Tables 1 to 3 give the Portland cement composition, the physical properties and characteristics of the dry PC and dry PCMK-1 blends and the characteristic cement strength (EN 196-1).

Tabla 1 / Table 1

Composición química del cemento Portland (PC) de referencia y la arena metacaolínica (MK-1). Chemical composition of the reference Portland cement (PC) and metakaolin (MK-1) sand.

\begin{tabular}{|c|c|c|}
\hline Componente, \% en peso / Component, wt\% & PC & MK- 1 \\
\hline Humedad / Humidity & 0.26 & 0.24 \\
\hline Pérdida por calcinación / Loss on ignition & 1.93 & 1.52 \\
\hline $\mathrm{SiO}_{2}$ & 20.87 & 62.91 \\
\hline Residuo insoluble / Insoluble residue & 1.48 & 2.73 \\
\hline $\mathrm{Fe}_{2} \mathrm{O}_{3}$ & 2.72 & 28.92 \\
\hline $\mathrm{Al}_{2} \mathrm{O}_{3}$ & 5.58 & 1.02 \\
\hline $\mathrm{CaO}$ & 61.33 & 0.94 \\
\hline $\mathrm{MgO}$ & 2.58 & 0.03 \\
\hline $\mathrm{SO}_{3}$ & 2.43 & \multicolumn{2}{|c|}{} \\
\hline
\end{tabular}

Tabla 2 / Table 2

Propiedades y características físicas del cemento Portland y las mezclas secas de PCMK-1. Physical properties and characteristics of Portland cement and dry PCMK-1 blends.

\begin{tabular}{|c|c|c|c|c|c|}
\hline $\begin{array}{l}\text { Sistema cementante / } \\
\text { Cement system }\end{array}$ & $\begin{array}{c}\text { Gravedad específica, } \\
\mathbf{k g} / \mathbf{m}^{3} / \\
\text { Specific gravity, } \\
\mathrm{kg} / \mathrm{m}^{3}\end{array}$ & $\begin{array}{c}\text { Área superficial } \\
\text { específica, } \mathbf{m}^{2} / \mathbf{k g} / \\
\text { Specific surface area, } \\
\mathrm{m}^{2} / \mathrm{kg}\end{array}$ & $\begin{array}{c}\text { Consistencia } \\
\text { normal / Normal } \\
\text { consistency, \% }\end{array}$ & $\begin{array}{c}\text { Tiempo de fraguado } \\
\text { inicial, } \\
\text { horas/minutos / } \\
\text { Initial setting time, } \\
\text { hours/minutes }\end{array}$ & $\begin{array}{c}\text { Tiempo de fraguado } \\
\text { final, } \\
\text { horas/minutos / } \\
\text { Final setting time, } \\
\text { hours/minutes }\end{array}$ \\
\hline $\mathrm{PC}$ & 3174 & 428.27 & 29.6 & $3 / 25$ & $4 / 40$ \\
\hline PCMK- $1 / 10$ & 3077 & 409.68 & 32.3 & $3 / 35$ & $4 / 40$ \\
\hline PCMK- 1/20 & 3051 & 415.97 & 38.0 & $3 / 50$ & $4 / 55$ \\
\hline PCMK- $1 / 40$ & 2995 & 605.21 & 41.7 & $3 / 40$ & $5 / 40$ \\
\hline
\end{tabular}


Tabla 3 / Table 3

Resistencia característica del cemento Portland (CEM I 42.5R). Characteristic strength for Portland cement (CEM I 42.5R).

\begin{tabular}{|c|c|c|c|}
\hline \multirow{2}{*}{ Cemento Portland / Portland cement } & \multicolumn{3}{|c|}{ Curado, días / Curing, days } \\
\cline { 2 - 4 } & $\mathbf{1}$ & $\mathbf{3}$ & $\mathbf{7}$ \\
\hline Resistencia a la flexión / Flexural strength, MPa & 3.8 & 7.6 & 9.6 \\
\hline Resistencia a la compresión / Compressive strength, MPa & 14.2 & 36.0 & 11.4 \\
\hline
\end{tabular}

\subsection{Preparación de las pastas, mezclas y morteros}

Se estudiaron dos sistemas de materiales: el cemento Portland de referencia (PC) y las mezclas compuestas por PC y arena metacaolínica (MK-1), aquí denominadas de forma abreviada PCMK-1. Las mezclas PCMK-1 no constituyen pastas de cemento típicas debido a la presencia de cuarzo $\left(\mathrm{SiO}_{2}\right)$ procedente de la arena. Por ese motivo, en el presente trabajo no se hace referencia a ellas como pastas sino como mezclas; la única pasta es la elaborada con el PC y agua. Las mezclas de PCMK-1 y las pastas de referencia de PC se prepararon utilizando una relación agua/sólido (w/s) constante de 0,5. Las mezclas y pastas se mezclaron con la misma amasadora mecánica que los morteros.

Tanto los morteros fabricados con las mezclas PCMK-1 como el mortero de referencia de PC se elaboraron con una arena silícea normalizada $(0-0,5 \mathrm{~mm}: 0,5-1 \mathrm{~mm}$ : 1-2 $\mathrm{mm}=1: 1: 1$ según el peso) y una relación de cemento/arena de $1: 3$ en peso. A diferencia de las mezclas y pastas, los morteros se elaboraron con la misma consistencia, concretamente con un asentamiento de $180 \pm 5$ $\mathrm{mm}$ determinado mediante el cono de Hagerman (EN 1015-3: Métodos de ensayo para morteros de albañilería. Determinación de la consistencia del mortero fresco por la mesa de sacudidas). Se agregaron pequeñas cantidades de superplastificantes $(<1-1,2 \%$ en peso de los sólidos) a los morteros PCMK-1 para lograr que tuvieran la misma consistencia que el mortero de referencia. Se considera que esta igual trabajabilidad justificaba que los morteros pudieran compararse entre sí.

Las probetas cúbicas de $20 \times 20 \times 20 \mathrm{~mm}$ en el caso de las mezclas y las pastas y las de $40 \times 40 \times 160 \mathrm{~mm}$ en el caso de los morteros, se vibraron en una mesa vibradora $(50 \mathrm{~Hz}$, $0,35 \mathrm{~mm}$ ) durante un máximo de 30 segundos en el caso de las mezclas y las pastas y de 60 segundos en el de los morteros. Tras un curado de un día a $20^{\circ} \mathrm{C}$ y a una HR del $100 \%$ (aire húmedo), se desmoldaron y se conservaron en agua a $20 \pm 0,5^{\circ} \mathrm{C}$, durante 28 y 90 días.

\subsection{Ensayos realizados}

La puzolanicidad de la arena MK-1 se determinó mediante la inmersión de la arena calcinada, con partículas de radio

\subsection{Paste, blend and mortar preparation}

Two material systems were studied: the reference Portland cement (PC) and the blends consisting of $P C$ and metakaolin sand (MK-1) abbreviated as PCMK-1. The PCMK-1 blends were not typical cement pastes because of the quartz $\left(\mathrm{SiO}_{2}\right)$ present in the sand. Hence these samples are not referred to here as pastes but as blends: the only paste was the material made with PC and water. The PCMK-1 blends and PC reference pastes were prepared with a constant water/solid $(w / s)$ ratio of 0.5 . The blends/pastes were mixed in the same mechanical mixer as the mortars.

Mortars containing the same PCMK-1 blends, as well as a $P C$ reference mortar, were made with standard siliceous sand (0-0.5 mm: 0.5-1 mm: $1-2 \mathrm{~mm}=1: 1: 1$ by weight) at a cement/sand ratio of $1: 3$ by weight. Unlike the blends/pastes, they were made to the same

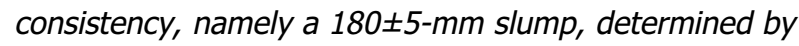
the Hagerman cone (EN 1015-3: Methods of test for mortar for masonry. Determination of consistence of fresh mortar by flow table). Small amounts of superplasticizer ( $<1-1.2 \%$ by weight of solids) were added to the PCMK-1 mortars to obtain the same consistency as in the reference mortar. Mortar comparability was based on this identical workability.

The cubic $(20 \times 20 \times 20 \mathrm{~mm})$ and prismatic $(40 \times 40 \times 160$ $\mathrm{mm})$ specimens for the blends/pastes and mortars, respectively, were vibrated on a vibrating table $(50 \mathrm{~Hz}$, $0.35 \mathrm{~mm}$ ) for a maximum of 30 seconds for the blends/pastes and 60 seconds for the mortars. After curing for 1 day at $20{ }^{\circ} \mathrm{C}$ and $100 \% \mathrm{RH}$ (wet air), they were removed from the moulds and stored in water at 20 $\pm 0.5^{\circ} \mathrm{C}$ for 28 or 90 days.

\subsection{Tests conducted}

MK-1 pozzolanicity was determined by soaking the calcined sand with a particle size radius of under $0.06 \mathrm{~mm}$ 
inferior a 0,06 mm, en una disolución saturada de cal a 40 $\pm 1{ }^{\circ} \mathrm{C}$ durante 1,7 o 28 días. Se analizó la concentración de $\mathrm{CaO}$ en la disolución al cabo de los tiempos de ensayo indicados. La cantidad total de cal fijada (mM/L) se calculó restando de la concentración de $\mathrm{CaO}$ en la disolución saturada de cal original el contenido de $\mathrm{CaO}$ en la disolución que permanecía en la muestra al final de cada periodo (12). La actividad puzolánica detectada en la MK-1 se comparó con la de otras puzolanas como un metacaolín comercial, un humo de sílice y una ceniza volante.

La velocidad de evolución de calor y el calor total liberado durante la hidratación del cemento se determinaron mediante el análisis por calorimetría de conducción de las pastas en un equipo TAM Air de Thermometric. Se pesaron cinco gramos de cada tipo de cemento y se mezclaron con agua no carbonatada, en una relación agua/sólido de 0,5. La mezcla se realizó manualmente en un vial durante tres minutos. El ensayo se mantuvo durante unas 200 horas y se controló la temperatura a $25^{\circ} \mathrm{C}$.

Se determinaron las propiedades mecánicas de los diferentes materiales. Los ensayos de porosidad se realizaron mediante un porosímetro por intrusión de mercurio (MIP) modelo Carlo Erba 2000 (Milán, Italia), así como con un "macro porosimeter" modelo 120. Se obtuvo el coeficiente de permeabilidad de las mezclas y morteros a partir de los resultados porosimétricos (volumen de microporos $<7.500 \mathrm{~nm}$, microporo promedio y radio medio de los poros, porosidad total y distribución del tamaño de los poros) usando el método propuesto en (13) y puesto en práctica en (14).

La composición química se determinó por métodos analíticos por vía húmeda habituales; así como con los procedimientos descritos en la norma europea EN 196-2. Se realizaron los análisis de difracción de rayos $X(D R X)$ con un difractómetro Philips de radiación CuK. y filtro de $\mathrm{Ni}$ acoplado a un sistema automático de registro de datos (20: $16^{\circ}$ a $36^{\circ}$ ). Los análisis de termogravimetría (TG) y el análisis térmico diferencial (ATD) (15) se realizaron simultáneamente a temperaturas entre 20 y $1.000{ }^{\circ} \mathrm{C}$ con un equipo de Derivatograph Q (1500 MOM, Budapest, Hungría). $200 \mathrm{mg}$ de muestra se sometieron al tratamiento térmico en corriente de aire, con una velocidad de calentamiento de $20{ }^{\circ} \mathrm{C}$ por minuto.

\section{RESULTADOS Y DISCUSIÓN}

\subsection{Actividad puzolánica}

En la Figura 1 se muestra la actividad puzolánica de la arena MK-1 y de otros materiales puzolánicos. Los resultados obtenidos demuestran que, a los 28 días, los valores de puzolanicidad de la arena MK-1 son similares a los in a saturated lime solution at $40 \pm 1{ }^{\circ} \mathrm{C}$ for 1,7 or 28 days. The $\mathrm{CaO}$ concentration in the solution was analyzed at the specified test time. The amount of lime fixed $(\mathrm{mM} / \mathrm{L})$ was calculated as the difference between the $\mathrm{CaO}$ concentration in the original saturated lime solution and the $\mathrm{CaO}$ content remaining in the solution covering the sample at the end of each period (12). The pozzolanic activity found for MK-1 was compared to the values for other pozzolans such as commercial metakaolin, silica fume and fly ash.

The heat flow rate and total heat released during cement hydration were determined by conduction calorimetry conducted on the pastes with a Thermometric TAM Air conduction calorimeter. Five grams of each cement system were weighed and mixed with non-carbonated water at a water/solid ratio of 0.5 and hand-mixed in a vial for three minutes. The test was run for around 200 hours at a constant temperature of $25^{\circ} \mathrm{C}$.

The mechanical properties of all the materials were determined. Pore structure was studied by mercury intrusion porosimetry (MIP) on a Carlo Erba (Milan, Italy) model 2000 porosimeter as well as on a model 120 macro porosimeter. The permeability coefficient was found for the blends and mortars from the MIP findings (volume of micropores $<7500 \mathrm{~nm}$, average micropore and pore median radius, total porosity and pore size distribution) using the method set out in (13) and implemented in (14).

The chemical composition was determined with standard wet analytical methods and the procedures described in European standard EN 196-2. Powder X- ray diffraction (XRD) patterns were recorded in the $16^{\circ}$ to $36^{\circ} 2 \theta$ range on a Philips diffractometer coupled to an automatic data recording system, using CuK radiation and an Ni filter. Thermogravimetry (TG) and differential thermal analysis (DTA) (15) were conducted simultaneously from 20 to $1000{ }^{\circ} \mathrm{C}$ on a Derivatograph $Q$ instrument (1500 MOM Budapest, Hungary). Samples weighing $200 \mathrm{mg}$ were heated in flowing air at a heating rate of $20^{\circ} \mathrm{C} /$ minute.

\section{RESULTS AND DISCUSSION}

\subsection{Pozzolanic activity}

The pozzolanic behaviour of $M K-1$ sand and the other pozzolans are shown in Figure 1. These findings revealed that at 28 days, MK-1 sand pozzolanicity values were similar to the values for pure metakaolin and silica fume 


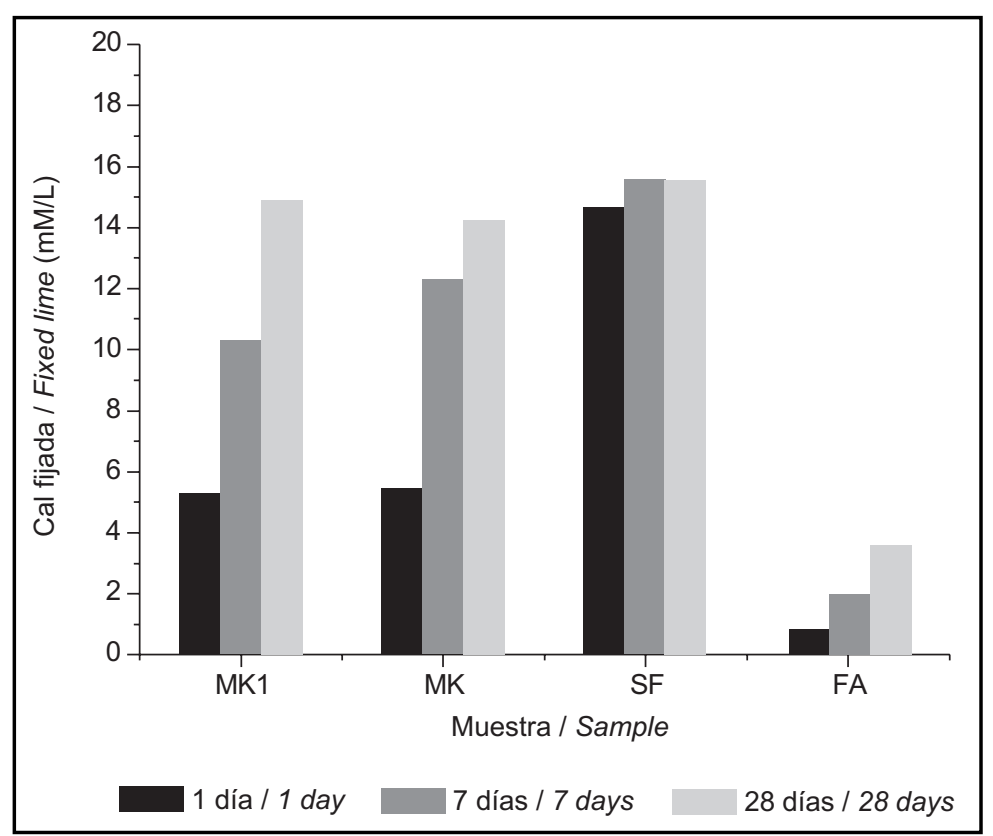

Figura 1. Actividad puzolánica en la arena MK-1 y otras puzolanas. MK: metacaolín comercial, SF: humo de sílice, FA: cenizas volantes (a efectos de comparación [datos de las referencias 6 a 12]).

Figure 1. Pozzolanic activity in MK-1 and other pozzolans MK: commercial metakaolin, SF: silica fume, FA: fly ash for comparison (data from references 6 to 12).

valores del metacaolín puro y del humo de sílice y superiores a los de la ceniza volante (clase F). Como era de esperar, el humo de sílice ha resultado ser la puzolana más activa. A edades más cortas, entre 1 y 7 días, la combinación de $\mathrm{CaO}$ de la arena MK-1 es ligeramente inferior a la del metacaolín comercial y sensiblemente menor al del humo de sílice; pero superiores a los de la ceniza volante.

\subsection{Estudios de calorimetría de conducción}

Según los resultados calorimétricos mostrados en la Figura 2 y en la Tabla 4, la adición de arena MK-1 al PC produce un ligero retraso en la aparición de la señal calorimétrica de mayor intensidad; pero fundamentalmente una menor intensidad en la señal. Este pico se asocia a la máxima precipitación de productos de reacción (portlandita y gel C-S-H) formados durante la hidratación del PC. and higher than for class F fly ash. As expected, silica fume proved to be the most active pozzolan. At earlier ages, between 1 and 7 days, the CaO combination in MK1 sand was slightly lower than in commercial metakaolin and substantially lower than in silica fume, but higher than in fly ash.

\subsection{Conduction calorimetry studies}

According to the calorimetric findings shown in Figure 2 and Table 4, the addition of MK-1 sand to PC induced a slight delay in the appearance but particularly a decline in the intensity of the highest intensity calorimetric signal. This signal is associated with peak precipitation of the reaction products (portlandite and $\mathrm{C}-\mathrm{S}-\mathrm{H}$ gel) formed during PC hydration. In the samples containing MK-1,

Tabla 4 / Table 4

Datos calorimétricos de la pasta de cemento de referencia y las mezclas PCMK-1. Calorimetric data for the reference cement paste and PCMK-1 blends.

\begin{tabular}{|c|c|c|c|c|c|c|c|}
\hline $\begin{array}{c}\text { Cemento / } \\
\text { Cement }\end{array}$ & $\begin{array}{c}\text { Tiempo de } \\
\text { inicio del pico / } \\
\text { Peak start } \\
\text { time h }\end{array}$ & $\begin{array}{c}\text { Tiempo de pico } \\
\text { máx / Peak } \\
\text { max. time h }\end{array}$ & $\begin{array}{c}\text { Velocidad máxima } \\
\text { de evolución de } \\
\text { calor / Max. heat } \\
\text { flow, J/g.h }\end{array}$ & $\begin{array}{c}\text { Tiempo final } \\
\text { del pico / Peak } \\
\text { end time, } \mathbf{h}\end{array}$ & $\begin{array}{l}\text { Duración del } \\
\text { pico / Peak } \\
\text { duration, h }\end{array}$ & $\begin{array}{c}\text { Calor liberado } \\
\text { durante el pico } \\
\text { / Peak heat } \\
\text { released, } \mathbf{J / g}\end{array}$ & $\begin{array}{c}\text { Calor total } \\
\text { liberado / Total } \\
\text { heat released, } \\
\mathbf{J} / \mathbf{g}\end{array}$ \\
\hline$P C$ & 1.87 & 12.98 & 9.15 & 96.86 & 94.99 & 272.03 & 310.12 \\
\hline PCMK1/10 & 2.11 & 13.27 & 8.61 & 90.49 & 88.38 & 239.98 & 266.15 \\
\hline PCMK1/20 & 2.15 & 12.98 & 8.17 & 114.54 & 112.39 & 249.25 & 296.68 \\
\hline PCMK1/40 & 2.29 & 13.64 & 5.71 & 142.44 & 140.15 & 211.66 & 235.09 \\
\hline
\end{tabular}




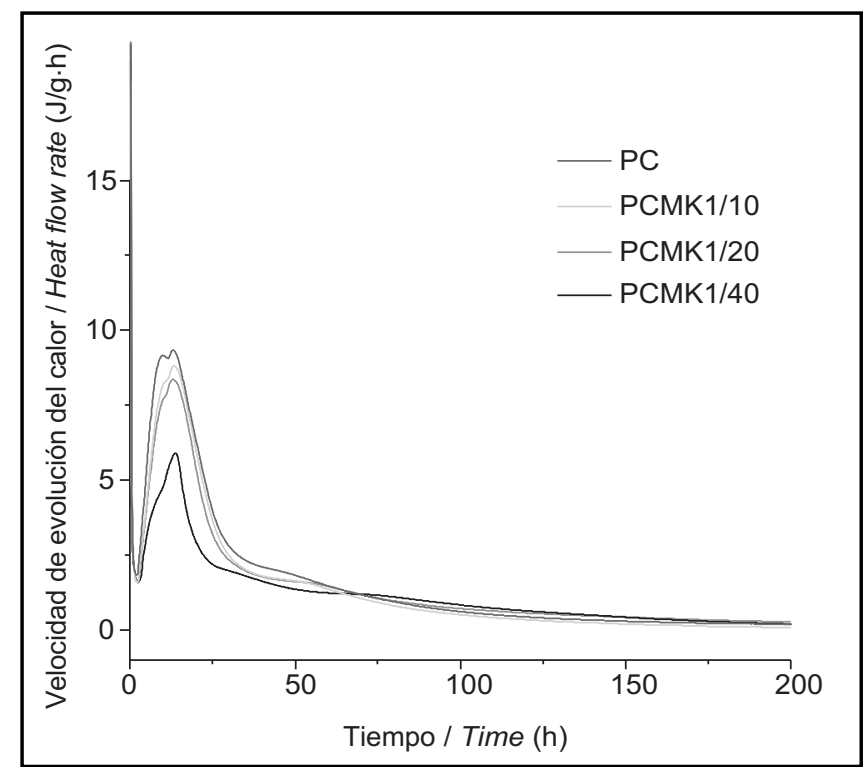

Figura 2. Datos calorimétricos de la pasta de PC de referencia y las mezclas PCMK-1. Figure 2. Calorimetry data for reference $P C$ paste and $P C M K-1$ blends.

Se observa un descenso en el máximo de la velocidad de evolución del calor en las muestras con arena MK-1, siendo este descenso progresivo según aumenta el contenido de MK-1 en las mezclas. Concretamente, en la mezcla con un $40 \%$ de MK-1 el máximo de la velocidad de evolución del calor es de $5,71 \mathrm{~J} / \mathrm{g} \cdot \mathrm{h}$, es decir, tan sólo un 37,5\% del máximo de la velocidad de evolución en la pastas de referencia $\mathrm{PC}$.

Se observa que al aumentar el contenido de arena MK-1 en las mezclas PCMK-1, se incrementa la duración del pico y se reducen la velocidad de evolución del calor y el calor total liberado. Todos estos efectos son más intensos en las probetas con el máximo contenido de arena MK-1 (40\%). Estos resultados indican que la presencia de la arena MK-1 en las mezclas, debido a su efecto diluyente en la mezcla final y a que su reacción puzolánica es más lenta en el tiempo que la hidratación del cemento, disminuye la intensidad de los procesos reactivos; y como consecuencia, la velocidad de desprendimiento de calor y el calor total emitido son menores que en la pasta de referencia.

\subsection{Resistencias mecánicas de pastas, mezclas y morteros}

En las Tablas 5 y 6 se muestran, respectivamente, los valores de resistencias mecánicas a la compresión de las mezclas de cemento y de los morteros. Independientemente de las diferencias del contenido en metacaolinita, de la superficie específica y de la consistencia normal (Tabla 2), a las edades de 28 y 90 días todas las mezclas PCMK-1 muestran una resistencia a la compresión inferior a la de la pasta de PC de referencia (en todos los the maximum heat flow rate declined progressively with increasing MK-1 content. Specifically, in blends with $40 \%$ $M K-1$ the maximum heat flow rate was $5.71 \mathrm{~J} / \mathrm{g} \cdot \mathrm{h}$, just $37.5 \%$ of the peak rate in PC paste.

Peak duration was observed to rise and the heat flow rate and total heat released to decline with increasing $M K-1$ sand content in the PCMK-1 blends. All these effects were more intense in the specimens with the highest (40\%) MK-1 sand content. These findings showed that due to its diluting effect on the final blend and the fact that its pozzolanic reaction is slower than cement hydration, the presence of $M K-1$ sand in the blends lowered the intensity of the reactions. As a result, the heat flow rate and total heat released were lower than in the reference paste.

\subsection{Mechanical strength in pastes, blends and mortars}

The mean compressive strength values for the cement blends and mortars are given in Tables 5 and 6, respectively. Regardless of the differences in metakaolinite content, specific surface area and normal consistency (Table 2), all of the 28- and 90-day PCMK-1 blends exhibited lower compressive strength than the reference $P C$ paste (with a $w / s$ ratio of 0.5 in all cases). The higher the replacement ratio, the lower was 
casos, la relación agua/sólido fue de 0,5). Cuanto mayor es el porcentaje de reemplazo, menores son las prestaciones, especialmente en las probetas curadas a 28 días. Las resistencias de todas las mezclas a los 90 días son muy similares y alrededor de $11-12 \mathrm{MPa}$ inferiores a la pasta de cemento de referencial. Estos resultados confirman que la dilución producida por la arena, obviamente, repercute negativamente en las resistencias a la compresión; aunque a 90 días este efecto es menor probablemente por el efecto positivo de la actividad puzolánica de la arena metacaolínica.

Por el contrario, en los morteros PCMK-1 preparados con la misma consistencia que los morteros de referencia, la incorporación de arena MK-1 con una proporción de un 5 y un $10 \%$ de metacaolinita se traduce en un incremento en la resistencia a la compresión respecto al mortero de referencia. El máximo aumento de la resistencia se produce tras el curado de 90 días y es más acusado cuando el PC se sustituye por arena MK-1 con un contenido del $5 \%$ de metacaolinita. En las muestras preparadas con un asentamiento constante de $180 \pm 5 \mathrm{~mm}$, pese a la dilución inherente al mezclado, se observa una visible mejora en las resistencias de los morteros PCMK1 con respecto al mortero de referencia. A la vista de los resultados positivos logrados mediante el ajuste de la consistencia del mortero con un superplastificante eficaz, se puede considerar que la arena MK-1 puede ser una adición aceptable al cemento y al hormigón, siempre y cuando se tengan en cuenta las consideraciones de consistencia adecuadas. performance, particularly in the 28-day specimens. Ninety-day strength was similar in all the blends and around 11-12 MPa lower than in the reference cement paste. These findings confirmed that the dilution induced by the sand obviously had an adverse impact on compressive strength, which was, however in all likelihood partially offset at 90 days by the beneficial effect of metakaolin sand pozzolanicity.

By contrast, in the PCMK-1 mortars prepared to the same consistency as the reference mortars, the inclusion of MK-1 sand containing 5 and 10\% (wt) metakaolinite, compressive strength was higher than in the control. Strength increased most in the 90-day samples and was most pronounced when the PC was replaced by $M K-1$ sand containing $5 \%$ (wt) of metakaolinite. In the samples prepared with a constant slump of $180 \pm 5 \mathrm{~mm}$, despite the dilution inherent in blending, visible strength gains were observed in the PCMK-1 mortars compared to the reference mortar. In light of the promising results obtained when mortar consistency was adjusted with an efficient superplasticizer, $M K-1$ sand may prove to be a suitable cement addition and concrete additive providing the right consistency is attained.

Tabla 5 / Table 5

Resistencia a la compresión de la pasta de cemento Portland de referencia y de las mezclas PCMK-1, a las edades de 28 días y a 90 días (agua/sólido $=$ constante $=0,5$ )

28- and 90-day compressive strength in reference Portland cement paste and PCMK-1 blends $(w /$ solid $=$ constant $=0.5)$

\begin{tabular}{|c|c|c|c|}
\hline $\begin{array}{l}\text { Sistema cementante / } \\
\text { Cement system }\end{array}$ & $\begin{array}{c}\text { Contenido en metacaolinita } \\
\text { de las mezclas PCMK-1 / } \\
\text { Metakaolinite content in } \\
\text { PCMK-1 blends \% }\end{array}$ & $\begin{array}{c}\text { Resistencia a la compresión } \\
\text { a los } 28 \text { días / } \\
\text { 28-day compressive strength, } \\
\mathrm{MPa}\end{array}$ & $\begin{array}{c}\text { Resistencia a la compresión } \\
\text { a los } 90 \text { días / } \\
\text { 90-day compressive strength, } \\
\text { MPa }\end{array}$ \\
\hline PC & - & 43.0 & 59.6 \\
\hline PCMK-1/10 & 3.6 & 41.2 & 48.9 \\
\hline PCMK-1/20 & 7.2 & 35.9 & 48.5 \\
\hline PCMK-1/40 & 14.4 & 29.3 & 48.0 \\
\hline
\end{tabular}

Tabla 6 / Table 6

Resistencia a la compresión del mortero de cemento Portland de referencia y del mortero PCMK-1, a las edades de 28 días y a 90 días (asentamiento: $180 \pm 5 \mathrm{~mm}$ ).

28- and 90-day compressive strength in reference Portland cement mortar and PCMK-1 mortar (slump: $180 \pm 5 \mathrm{~mm}$ ).

\begin{tabular}{|c|c|c|c|}
\hline Mortero / Mortar & $\begin{array}{c}\text { Contenido en metacaolinita } \\
\text { del mortero PCMK-1 / } \\
\text { Metakaolinite } \\
\text { content in PCMK-1 mortar, \% }\end{array}$ & $\begin{array}{l}\text { Resistencia a la compresión } \\
\text { a los } 28 \text { días / } \\
\text { 28-day compressive strength, } \\
M P a\end{array}$ & $\begin{array}{c}\text { Resistencia a la compresión } \\
\text { a los } 90 \text { días / 90-day } \\
\text { compressive strength, MPa }\end{array}$ \\
\hline PC & - & 40.2 & 53.5 \\
\hline 5 PCMK-1 & 5 & 72.2 & 86.2 \\
\hline 10PCMK-1 & 10 & 68.6 & 83.6 \\
\hline
\end{tabular}




\subsection{Estructura porosa de pastas, mezclas y morteros}

La resistencia no es la única variable que permite poner de manifiesto la validez tecnológica de las mezclas de cemento y de los morteros elaborados con MK1 ; también la permeabilidad de estos materiales, calculada mediante porosimetría, permite validar la calidad de las mezclas y de los morteros estudiados. Los resultados de la porosimetría de estos materiales, mezclas y morteros, se muestran en las Tablas 7 y 8 , respectivamente. Analizando estas tablas, se deduce que a los 28, 90 días de curado (edad en la que disminuye el contenido de $\mathrm{Ca}(\mathrm{OH})_{2}$ por la reacción puzolánica de la arena), tanto el radio medio del poro como los coeficientes de permeabilidad son inferiores, en todas las mezclas PCMK-1, a los de la pasta de referencia (ver Tabla 7). El tamaño medio del poro y

\subsection{Paste, blend and mortar pore structure}

Strength is not the only variable that reflects the technological validity of cement blends and mortars made with $M K-1$. The permeability of these materials, calculated from MIP pore structure data, also substantiates the quality of the blends and mortars studied. The MIP findings for the blends and mortars studied are summarized in Tables 7 and 8, respectively. The tables show that for all the 28 - and 90-day PCMK-1 blends (the ages when the $\mathrm{Ca}(\mathrm{OH})_{2}$ content declined due to the pozzolanic reaction in the sand), the average pore radius and permeability coefficients were lower than in the reference paste (see Table 7). The average pore size and the permeability coefficient also declined with curing time. These MIP findings were not fully consistent with the

Tabla 7 / Table 7

Estructura porosa de la pasta PC de referencia y de las mezclas PCMK-1. Pore structure of the reference PC paste and PCMK-1 blends.

\begin{tabular}{|c|c|c|c|c|c|c|c|c|c|c|}
\hline $\begin{array}{c}\text { Sistema } \\
\text { cementante / } \\
\text { Cement } \\
\text { system }\end{array}$ & $\begin{array}{c}\text { Edad, días/ } \\
\text { Age, days }\end{array}$ & SSA, $\mathrm{m}^{2} / \mathrm{g}$ & $\begin{array}{c}\text { VTP, } \\
\mathrm{mm}^{3} / \mathrm{g}\end{array}$ & $\begin{array}{c}\text { VMP, } \\
\mathrm{mm}^{3} / \mathrm{g}\end{array}$ & Macro, \% & MTP, nm & MMP, nm & $\begin{array}{c}B D, \\
\mathrm{~kg} / \mathrm{m}^{3}\end{array}$ & TP, \% & $\begin{array}{c}\mathrm{K} \times 10-10 \\
\mathrm{~m} / \mathrm{s}\end{array}$ \\
\hline PC & $\begin{array}{l}28 \\
90\end{array}$ & $\begin{array}{l}19.46 \\
24.89\end{array}$ & $\begin{array}{l}201.20 \\
181.22\end{array}$ & $\begin{array}{l}192.79 \\
171.99\end{array}$ & $\begin{array}{l}4.18 \\
5.09\end{array}$ & $\begin{array}{l}34.35 \\
23.70\end{array}$ & $\begin{array}{l}31.47 \\
21.04\end{array}$ & $\begin{array}{l}1460 \\
1440\end{array}$ & $\begin{array}{l}29.37 \\
26.09\end{array}$ & $\begin{array}{l}2.3 \\
0.7\end{array}$ \\
\hline PCMK-1/10 & $\begin{array}{l}28 \\
90\end{array}$ & $\begin{array}{l}22.43 \\
23.59\end{array}$ & $\begin{array}{l}174.06 \\
163.02\end{array}$ & $\begin{array}{l}163.28 \\
152.23\end{array}$ & $\begin{array}{l}6.19 \\
6.62\end{array}$ & $\begin{array}{l}29.49 \\
17.54\end{array}$ & $\begin{array}{l}26.01 \\
15.94\end{array}$ & $\begin{array}{l}1570 \\
1350\end{array}$ & $\begin{array}{l}27.32 \\
22.00\end{array}$ & $\begin{array}{l}1.6 \\
0.3\end{array}$ \\
\hline PCMK-1/20 & $\begin{array}{l}28 \\
90\end{array}$ & $\begin{array}{l}21.77 \\
22.90\end{array}$ & $\begin{array}{l}189.00 \\
147.69\end{array}$ & $\begin{array}{l}179.91 \\
143.42\end{array}$ & $\begin{array}{l}4.81 \\
2.89\end{array}$ & $\begin{array}{l}27.34 \\
15.57\end{array}$ & $\begin{array}{l}24.81 \\
14.86\end{array}$ & $\begin{array}{l}1570 \\
1450\end{array}$ & $\begin{array}{l}29.67 \\
21.41\end{array}$ & $\begin{array}{l}1.2 \\
0.4\end{array}$ \\
\hline PCMK-1/40 & $\begin{array}{l}28 \\
90\end{array}$ & $\begin{array}{l}25.97 \\
30.08\end{array}$ & $\begin{array}{l}219.67 \\
208.08\end{array}$ & $\begin{array}{l}209.79 \\
192.97\end{array}$ & $\begin{array}{l}4.50 \\
7.26\end{array}$ & $\begin{array}{l}29.85 \\
17.71\end{array}$ & $\begin{array}{l}26.76 \\
16.39\end{array}$ & $\begin{array}{l}1410 \\
1320\end{array}$ & $\begin{array}{l}30.97 \\
27.46\end{array}$ & $\begin{array}{l}2.1 \\
0.5\end{array}$ \\
\hline
\end{tabular}

Abreviaturas de los parámetros de la estructura porosa: SSA-superficie específica de los poros; $\mathrm{V}_{\mathrm{TP}}$-volumen total de poros abiertos (entre 3,7 $\mathrm{nm}$ y $0,06 \mathrm{~mm}$ ); $V_{M P}$-volumen de microporos (entre 3,7 y $7500 \mathrm{~nm}$ ); macro-proporción de macroporos (superiores a $7500 \mathrm{~nm}$ ); MTP-mediana de radio del poro; $\mathrm{M}_{\mathrm{MP}}$-mediana del radio del microporo; $\mathrm{BD}$-densidad aparente; TP-porosidad abierta total (entre 3,7 nm y 0,06 mm), $\mathrm{K}$-coeficiente de permeabilidad calculado. / Pore structure parameter abbreviations: SSA-specific surface area of pores; $V_{T P}$-total open pore volume (in the $3.7 \mathrm{~nm}-0.06 \mathrm{~mm}$ range); $V_{M P}$-volume of micropores (in the 3.7-7500 $\mathrm{nm}$ range); Macro-portion of macropores (over $7500 \mathrm{~nm}$ ); $M_{T P}-\mathrm{median}$ pore radius; $M_{M P}$-median micropore radius; BD-bulk density; TP-total open porosity (in the $3.7 \mathrm{~nm}-0.06 \mathrm{~mm}$ range), $\mathrm{K}$-calculated permeability coefficient.

Tabla 8 / Table 8

Estructura porosa del PC de referencia y de los morteros PCMK-1. Pore structure in reference $P C$ and PCMK-1 mortars.

\begin{tabular}{|c|c|c|c|c|c|c|c|c|c|c|}
\hline $\begin{array}{c}\text { Mortero / } \\
\text { Mortar }\end{array}$ & $\begin{array}{c}\text { Curado, } \\
\text { días }\end{array}$ & SSA, $\mathrm{m}^{2} / \mathrm{g}$ & $\begin{array}{c}\mathrm{V}_{\mathrm{TP} r} \\
\mathrm{~mm}^{3} / \mathrm{g}\end{array}$ & $\begin{array}{c}V_{\mathrm{MP}} \\
\mathrm{mm}^{3} / \mathrm{g}\end{array}$ & Macro, \% & $\mathbf{M}_{\mathrm{TP}}, \mathrm{nm}$ & $\mathbf{M}_{\mathrm{MP},} \mathbf{n m}$ & $B D, \mathbf{k g} / \mathrm{m}^{3}$ & TP, \% & $\begin{array}{c}K \times 10^{-10} \\
\mathrm{~m} / \mathrm{s}\end{array}$ \\
\hline PC & 90 & 8.33 & 65.55 & 56.40 & 13.96 & 39.14 & 29.10 & 2180 & 14.28 & 1.2 \\
\hline 5 PCMK-1 & 90 & 3.74 & 31.29 & 24.90 & 20.43 & 27.84 & 21.03 & 2210 & 6.91 & 0.5 \\
\hline 10 PCMK-1 & 90 & 5.34 & 45.51 & 39.04 & 14.21 & 21.28 & 18.50 & 2160 & 9.82 & 0.5 \\
\hline
\end{tabular}

Abreviaturas de los parámetros de la estructura porosa: SSA-superficie específica de los poros; $\mathrm{V}_{\mathrm{TP}}$-volumen total de poros abiertos (entre 3,7

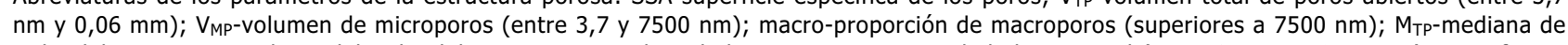
radio del poro; $\mathrm{M}_{\mathrm{MP}}$-mediana del radio del microporo; $\mathrm{BD}$-densidad aparente; TP-porosidad abierta total (entre 3,7 nm y 0,06 mm), $\mathrm{K}$-coeficiente de permeabilidad calculado. / Pore structure parameter abbreviations: SSA-specific surface area of pores; $V_{T P}$-total open pore volume (in the $3.7 \mathrm{~nm}-0.06 \mathrm{~mm}$ range); $V_{M P}$-volume of micropores (in the 3.7-7500 nm range); Macro-portion of macropores (over $7500 \mathrm{~nm}$ ); $M_{T P}-m e d i a n$ pore radius; $M_{M P}$-median micropore radius; BD-bulk density; TP-total open porosity (in the $3.7 \mathrm{~nm}-0.06 \mathrm{~mm}$ range), $\mathrm{K}$-calculated permeability coefficient. 
el coeficiente de permeabilidad también disminuyen con el tiempo de curado. Estos resultados no son totalmente coherentes con los datos relacionados con el desarrollo resistente en las mezclas PCMK-1. La resistencia a la compresión disminuye según aumenta el porcentaje de MK-1 en las mezclas (Figura 3). La menor permeabilidad se obtiene en la mezcla PCMK$1 / 10$, que contienen un $3,6 \%$ de metacaolinita, mientras que la más alta se observa siempre en la pasta del PC de referencia. Son necesarios más estudios para encontrar una explicación a esta incoherencia. Los morteros que contienen arena MK-1 presentan una porosidad más baja, un radio medio de poro y permeabilidad menores que el mortero de referencia (ver Tabla 8), lo que indica que la arena MK-1 refina de un modo eficaz la estructura porosa del mortero. strength development in PCMK-1 blends. Compressive strength declined with higher replacement ratios (Figure 3). The lowest permeability was found for PCMK-1/10 containing $3.6 \%$ (wt) metakaolinite, while it was always highest in the reference $P C$ paste. Further research is required to provide an explanation for this inconsistency. The mortars containing $M K-1$ sand had lower porosity, smaller mean pore radii and lower permeability than the reference mortar (see Table 8), indications that the MK-1 sand effectively refined the $P C$ mortar pore structure.

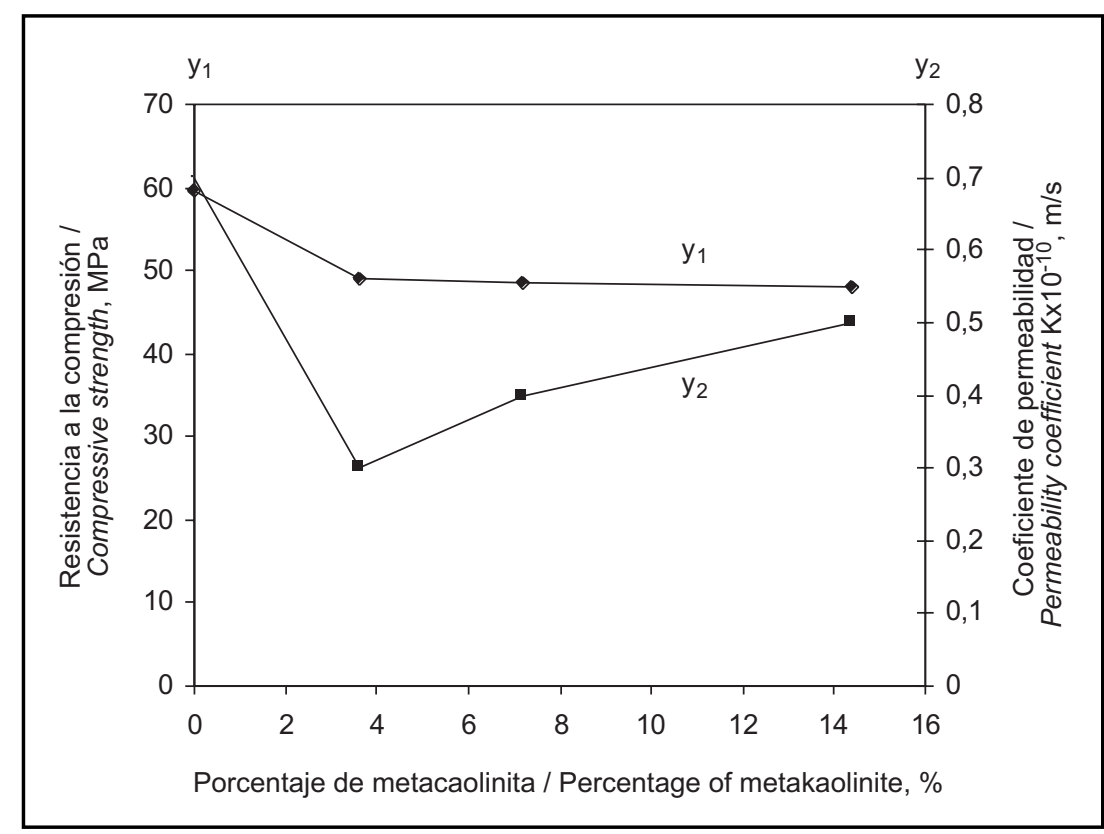

Figura 3. Resistencia a la compresión (eje $\mathrm{y}_{1}$ ) y coeficiente de permeabilidad (eje $\mathrm{y}_{2}$ ), tras un curado de 90 días, comparados con el contenido de metacaolinita de las mezclas PCMK-1 y la pasta de PC de referencia.

Figure 3. 90-day compressive strength (axis $y_{1}$ ) and permeability coefficient (axis $y_{2}$ ) versus metakaolinite content for PCMK-1 blends and the reference $P C$ paste.

La influencia de la arena MK-1 en la distribución del tamaño del poro en las mezclas de cemento y en los morteros se refleja en las Figuras 5 y 7 , mientras que los resultados obtenidos para las probetas de referencia se encuentran en las Figuras 4 y 6 . La mezcla PCMK-1 muestra una mayor proporción de poros más pequeños que las probetas de referencia. Se ha comprobado que este efecto positivo de la adición de arena MK-1 al PC aumenta progresivamente a medida que se incrementan el porcentaje de reemplazo y la edad.
The effect of MK-1 sand on the pore size distribution of cement blends and mortars is shown in Figures 5 and 7, while the findings for the reference specimens are depicted in Figures 4 and 6. The PCMK-1 blend exhibited a greater proportion of finer pores than the reference specimens. This beneficial effect of the addition of $M K-1$ sand to $P C$ was found to increase gradually with both higher replacement ratios and age. 


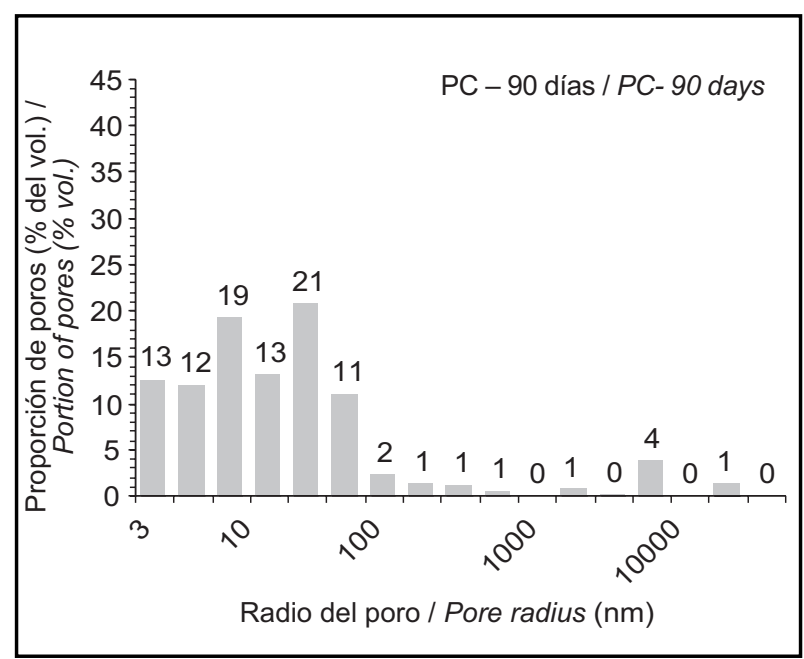

Figura 4. Distribución del tamaño de los poros de la pasta PC a la edad de 90 días.

Figure 4. Pore size distribution of 90-day PC paste.

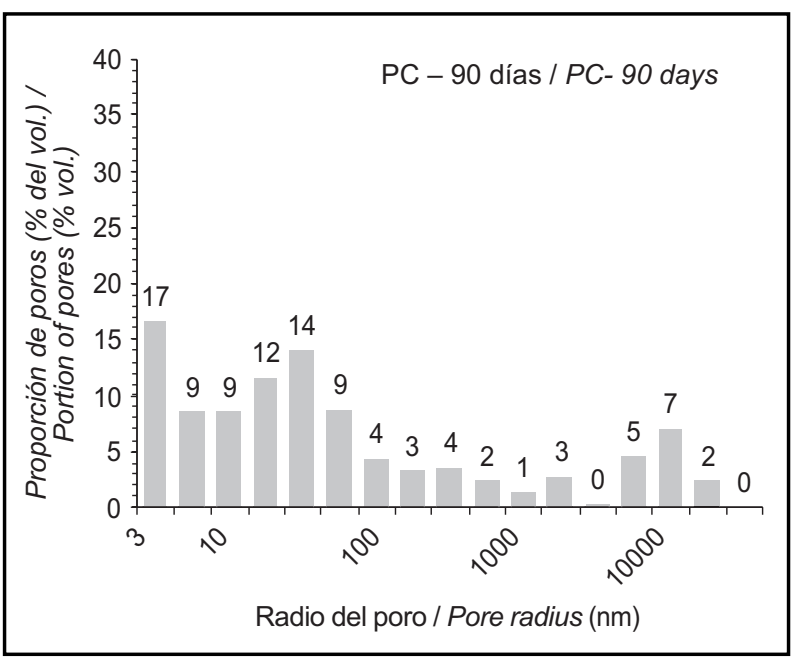

Figura 6. Distribución del tamaño de los poros del mortero de PC tras un curado de 90 días.

Figure 6. Pore size distribution in 90-day PC mortar.

\subsection{Caracterización por DRX y ATD-TG y análisis químicos}

Los difractogramas de las diferentes pastas y mezclas de cemento con la arena MK-1 se muestran en la Figura 8 , y los resultados obtenidos confirman los resultados previos de puzolanicidad. En esta figura se observa que, a los 90 días de curado, en las mezclas PCMK-1 se detecta menos hidróxido de calcio $(\mathrm{CH})$; y que este consumo es más pronunciado en las mezclas con mayores porcentajes de reemplazo; debido, por una parte al

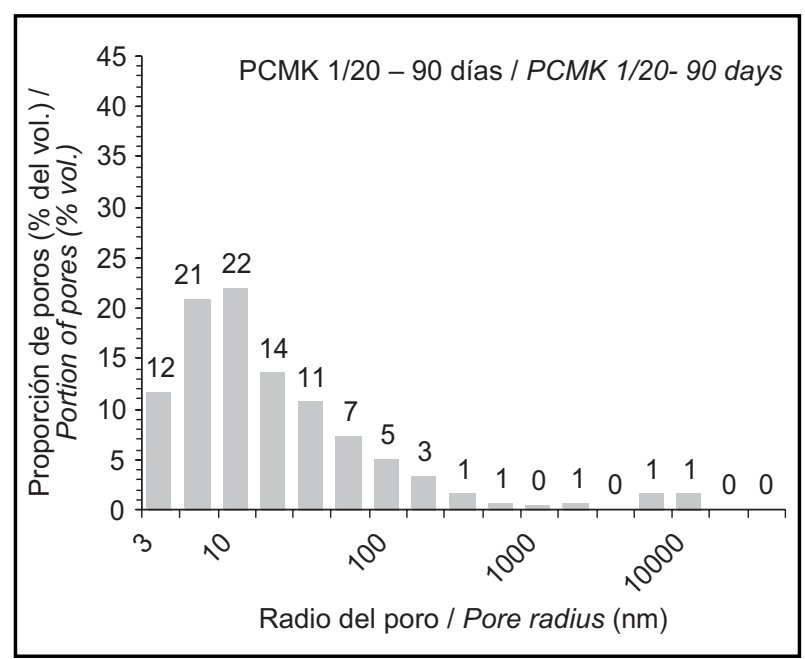

Figura 5. Distribución del tamaño de los poros de la mezcla PCMK-1/20 tras un curado de 90 días (el PC se sustituye por MK-1 con un contenido del 7,2 \% de metacaolinita). Figure 5. Pore size distribution of 90-day PCMK-1/20 blend (PC replaced MK-1 containing 7.2 wt\% of metakaolinite).

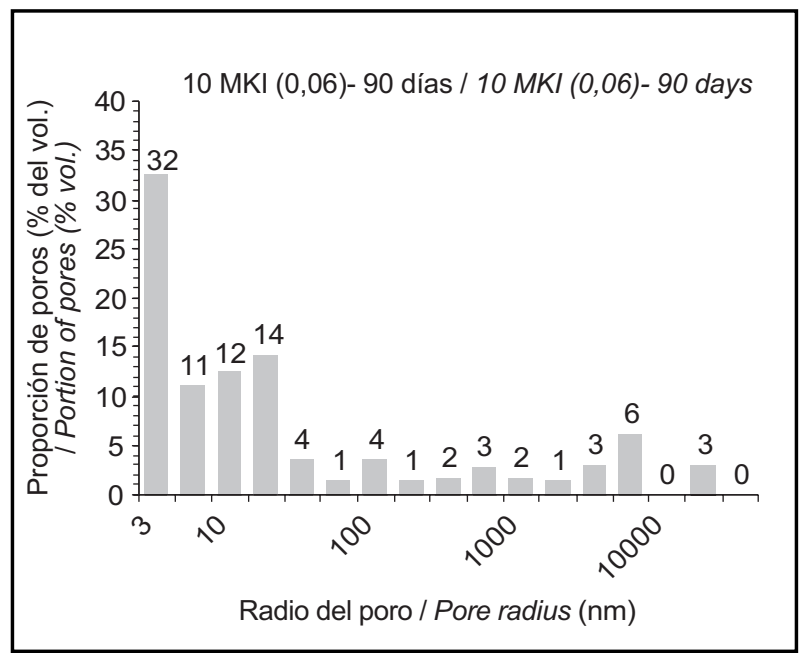

Figura 7. Distribución del tamaño de los poros del mortero PCMK-1 tras un curado de 90 días (el PC se sustituye por MK-1 con un contenido del $10 \%$ de metacaolinita).

Figure 7. Pore size distribution in 90-day PCMK-1 mortar (PC replaced with MK-1 containing 10\% (wt) of metakaolinite).

\subsection{XRD and TG-DTA characterization and chemical analysis}

The XRD traces for the cement and $M K-1$ sand pastes and blends shown in Figure 8 confirmed the pozzolanicity findings. According to these diffractograms, less calcium hydroxide $(\mathrm{CH})$ was detected in the 90-day PCMK-1 blends. Uptake was more intense in the blends with higher replacement ratios due to both the dilution effect and the pozzolanic reaction. The XRD traces for the $P C M K-1$ blends revealed the presence of quartz $(Q)$ and 
efecto diluyente y otro a la reacción puzolánica. Los difractogramas de las mezclas PCMK-1 indican la presencia de cuarzo (Q) y moscovita $(\mathrm{Mu})$, ambas procedentes de la arena MK-1 y, por lo tanto, ausentes en la pasta de referencia. muscovite (Mu), both from the MK-1 sand and therefore absent in the reference paste.

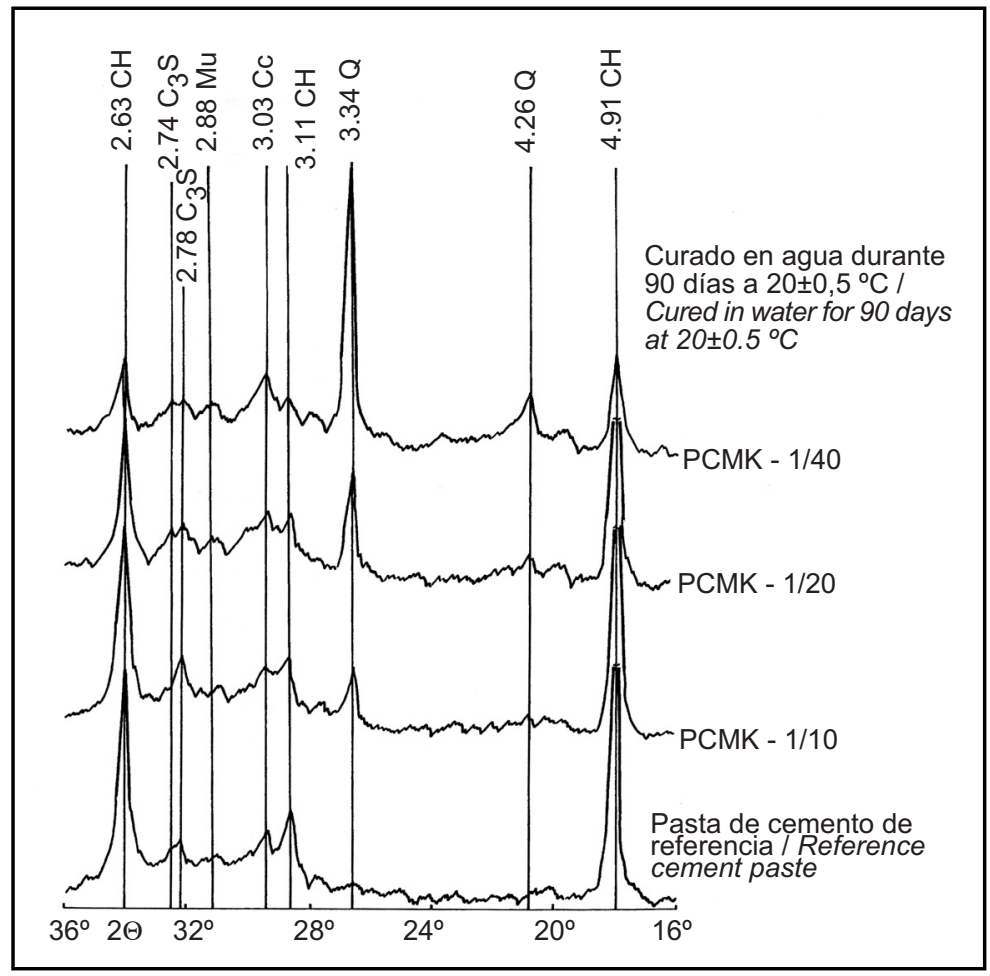

Figura 8. Productos de la reacción de hidratación de la pasta de cemento Portland (PC) de referencia y de las mezclas PCMK-1, a la edad de 90 días $\left[\mathrm{CH}=\mathrm{Ca}(\mathrm{OH})_{2}, \mathrm{Cc}-\mathrm{CaCO}_{3}, \mathrm{C}_{3} \mathrm{~S}\right.$-material clínker sin reaccionar procedente del PC; Q y Mu-cuarzo y moscovita procedentes de la MK-1].

Figure 8. Hydration reaction products in 90-day reference Portland cement paste $(P C)$ and $P C M K-1$ blends $\left[C H=C a(O H)_{2}\right.$, $\mathrm{CC}_{\mathrm{CaCO}}, \mathrm{C}_{3} \mathrm{~S}$-unreacted clinker mineral present in PC; $Q$ and Mu-quartz and muscovite present in MK-1].

El hecho de que el consumo de $\mathrm{CH}$ sea mayor en las mezclas que en la pasta de referencia es debido a la reacción puzolánica de la arena, y se confirma también por los resultados de ATD-TG. A $490{ }^{\circ} \mathrm{C}$ se observan (Figura 9) y se calculan (Tabla 9) cantidades menores de $\mathrm{CH}$ en las mezclas PCMK-1 que en la pasta de PC. Estos resultados también confirman el consumo de $\mathrm{CH}$ como resultado de la reacción puzolánica entre la arena MK-1 y el cemento.

No obstante, los valores empíricos de consumo de $\mathrm{CH}$ son inferiores a lo esperado, siendo dicho consumo claramente apreciable sólo en el caso de la mezcla PCMK1/40. La existencia de la reacción puzolánica en la mezcla que contiene un $40 \%$ de arena MK-1 queda totalmente demostrada mediante los análisis de DRX y ATD-T; confirmando los resultados de puzolanicidad descritos anteriormente. Al mismo tiempo, se observa que la trabajabilidad del mortero fresco desciende en los materiales con un porcentaje de reemplazo del $40 \%$. No
The reason that $\mathrm{CH}$ uptake was greater in the blends than in the reference paste was the existence of the pozzolanic reaction in the sand, which was also confirmed by the DTA-TG findings. Smaller amounts of $\mathrm{CH}$ were calculated (Table 9) and visible (Figure 9) at $490{ }^{\circ} \mathrm{C}$ in the PCMK-1 blends than in the PC paste. These observations also confirmed $\mathrm{CH}$ uptake as a result of the pozzolanic reaction between $M K-1$ sand and the cement.

Expected $\mathrm{CH}$ uptake was higher than the empirical values, however, and was clearly visible in the PCMK$1 / 40$ blend only. The existence of the pozzolanic reaction was fully proven by XRD and TG-DTA for the blend containing $40 \%$ (wt) of $M K-1$ sand, confirming the pozzolanicity findings described earlier. At the same time, fresh mortar workability was found to decline in the materials with a $40 \%$ (wt) replacement ratio. Nonetheless, pore structure refinement and the resulting extremely low permeability coefficients were detected by 


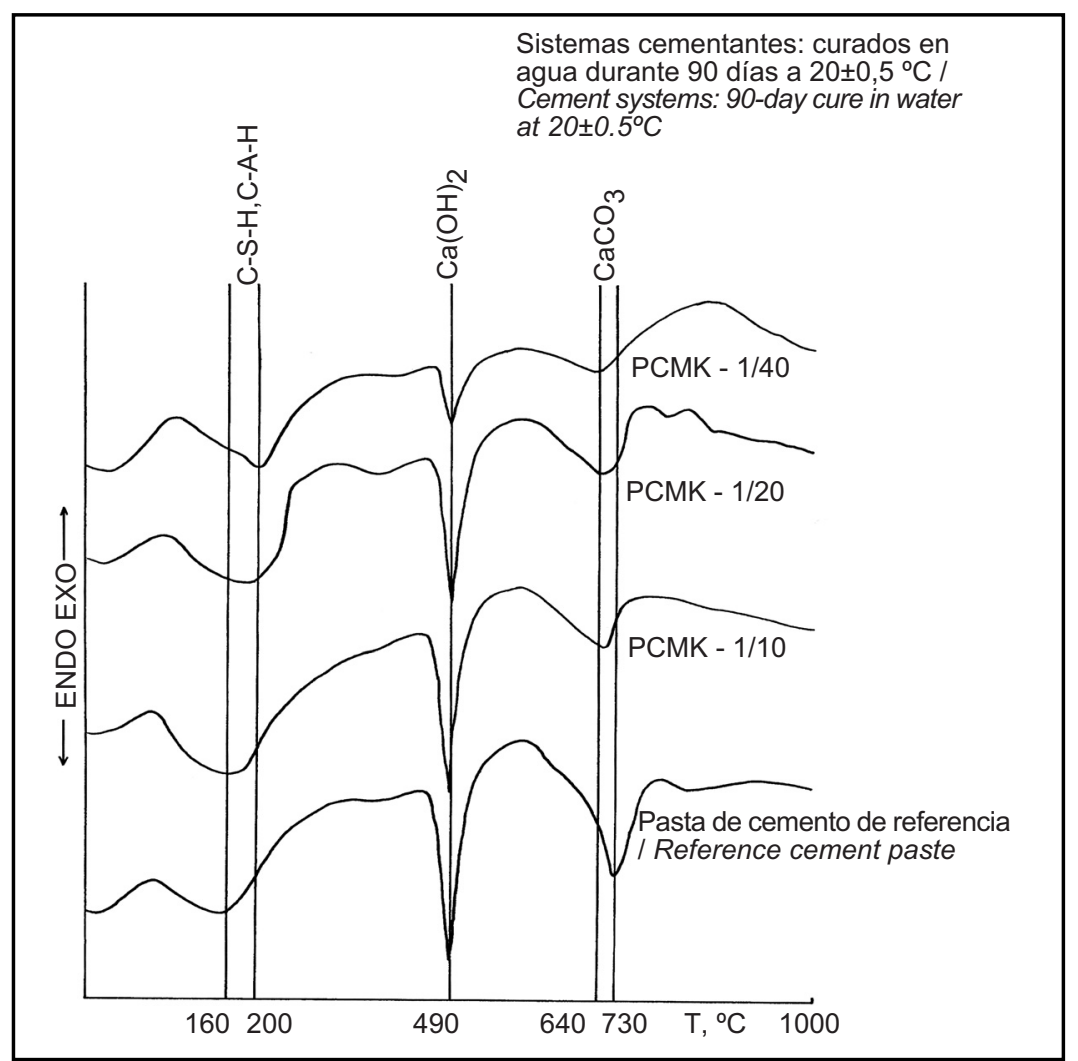

Figura 9. Composición por fases de la pasta de PC y las mezclas PCMK-1 a la edad de 90 días. Figure 9. Phase composition in 90-day PC paste and PCMK-1 blends.

Tabla 9 / Table 9

Resultados de los análisis térmicos - Cálculos TG. Results of thermal analysis - TG calculations.

\begin{tabular}{|c|c|c|c|c|c|c|}
\hline $\begin{array}{c}\text { Sistema } \\
\text { cementante / } \\
\text { Cement } \\
\text { system }\end{array}$ & $\begin{array}{l}\text { Edad, } \\
\text { Días / } \\
\text { Age, } \\
\text { days }\end{array}$ & $\begin{array}{l}\text { Agua estructural } \\
\text { superficial / } \\
\text { Surface } \\
\text { bound water, } \\
\%\end{array}$ & $\begin{array}{c}\text { Agua estructural } \\
\text { en C-S-H, C-A-H / } \\
\text { Bound water in } \\
C-S-H, C-A-H, \\
\%\end{array}$ & $\begin{array}{c}\text { Agua estructural } \\
\text { en } \mathrm{Ca}(\mathrm{OH})_{2} / \\
\text { Bound water in } \\
\mathrm{Ca}(\mathrm{OH})_{2} \\
\%\end{array}$ & $\begin{array}{c}\mathrm{CO}_{2} \text { estructural } \\
\text { en } \mathrm{CaCO}_{3} / \\
\text { Bound } \mathrm{CO}_{2} \\
\text { in } \mathrm{CaCO}_{3} \\
\%\end{array}$ & $\begin{array}{c}\text { Pérdida por } \\
\text { calcinación } \\
\text { total / Total } \\
\text { loss on ignition, } \\
\%\end{array}$ \\
\hline PC & $\begin{array}{l}28 \\
90\end{array}$ & $\begin{array}{l}1.00 \\
2.00\end{array}$ & $\begin{array}{l}10.50 \\
11.50\end{array}$ & $\begin{array}{l}3.50 \\
3.01\end{array}$ & $\begin{array}{l}4.00 \\
4.83\end{array}$ & $\begin{array}{l}20.00 \\
23.00\end{array}$ \\
\hline PCMK-1/10 & $\begin{array}{l}28 \\
90\end{array}$ & $\begin{array}{l}1.25 \\
2.00\end{array}$ & $\begin{array}{l}10.25 \\
12.00\end{array}$ & $\begin{array}{l}3.00 \\
3.01\end{array}$ & $\begin{array}{l}3.50 \\
3.25\end{array}$ & $\begin{array}{l}19.25 \\
21.50\end{array}$ \\
\hline PCMK-1/20 & $\begin{array}{l}28 \\
90\end{array}$ & $\begin{array}{l}1.50 \\
2.00\end{array}$ & $\begin{array}{l}10.25 \\
12.25\end{array}$ & $\begin{array}{l}2.75 \\
2.50\end{array}$ & $\begin{array}{l}3.00 \\
2.77\end{array}$ & $\begin{array}{l}18.50 \\
20.75\end{array}$ \\
\hline PCMK-1/40 & $\begin{array}{l}28 \\
90\end{array}$ & $\begin{array}{l}1.50 \\
1.75\end{array}$ & $\begin{array}{c}9.75 \\
12.00\end{array}$ & $\begin{array}{l}1.75 \\
0.99\end{array}$ & $\begin{array}{l}2.50 \\
2.21\end{array}$ & $\begin{array}{l}16.50 \\
18.25\end{array}$ \\
\hline
\end{tabular}

obstante, los resultados de la porosimetría indican un refinamiento de la estructura porosa $y$, por consiguiente, unos coeficientes de permeabilidad extremadamente bajos en los morteros con un contenido de MK-1 inferior al $40 \%$.

Las mezclas PCMK-1 se caracterizan por tener contenidos en $\mathrm{CaO}$ inferiores y valores superiores de residuo insoluble que la pasta de referencia (Tabla 10). Los cambios mencionados en la composición química se deben a la adición de MK-1 (que contiene Q y Mu).
MIP in mortars with an MK-1 content of less than $40 \%$ (wt).

The PCMK-1 blends were characterized by lower $\mathrm{CaO}$ contents and higher insoluble residue values than the reference paste (Table 10). The aforementioned changes in chemical composition were induced by the addition of (Q- and Mu-containing) $M K-1$. 
Tabla 10 / Table 10

Composición química de la pasta de PC y la mezcla PCMK-1. Chemical composition of PC paste and PCMK-1 blend.

\begin{tabular}{|c|c|c|c|c|c|c|c|c|c|c|}
\hline \multirow[b]{2}{*}{$\begin{array}{c}\text { Sistema } \\
\text { cementante / } \\
\text { Cement } \\
\text { system }\end{array}$} & \multirow[b]{2}{*}{$\begin{array}{l}\text { Edad, } \\
\text { días / } \\
\text { Age, } \\
\text { days }\end{array}$} & \multicolumn{9}{|c|}{ Componente, \% en peso / Component, wt\% } \\
\hline & & $\begin{array}{c}\text { Humedad / } \\
\text { Humidity, } \\
100^{\circ} \mathrm{C}\end{array}$ & $\begin{array}{c}\text { Pérdida por } \\
\text { calcinación/ } \\
\text { Loss on } \\
\text { ignition } \\
1000^{\circ} \mathrm{C}\end{array}$ & $\mathrm{SiO}_{2}$ & $\mathrm{Fe}_{2} \mathrm{O}_{3}$ & $\mathrm{Al}_{2} \mathrm{O}_{3}$ & $\mathrm{CaO}$ & MgO & $\mathrm{SO}_{3}$ & $\begin{array}{c}\text { Residuo } \\
\text { insoluble/ } \\
\text { Ins. } \\
\text { residue }\end{array}$ \\
\hline PC & $\begin{array}{l}28 \\
90\end{array}$ & $\begin{array}{l}3.71 \\
3.55\end{array}$ & $\begin{array}{l}16.71 \\
18.93\end{array}$ & $\begin{array}{l}17.38 \\
17.00\end{array}$ & $\begin{array}{l}2.38 \\
2.30\end{array}$ & $\begin{array}{l}4.59 \\
4.25\end{array}$ & $\begin{array}{l}49.03 \\
49.20\end{array}$ & $\begin{array}{l}2.58 \\
1.00\end{array}$ & $\begin{array}{l}2.06 \\
1.89\end{array}$ & $\begin{array}{l}1.48 \\
0.90\end{array}$ \\
\hline $\begin{array}{c}\text { PCMK- } \\
1 / 10\end{array}$ & $\begin{array}{l}28 \\
90\end{array}$ & $\begin{array}{l}2.99 \\
3.56\end{array}$ & $\begin{array}{l}16.47 \\
18.54\end{array}$ & $\begin{array}{l}16.91 \\
17.09\end{array}$ & $\begin{array}{l}2.19 \\
2.10\end{array}$ & $\begin{array}{l}5.66 \\
5.44\end{array}$ & $\begin{array}{l}45.10 \\
44.47\end{array}$ & 2.081 .10 & $\begin{array}{l}1.83 \\
1.75\end{array}$ & $\begin{array}{l}6.19 \\
5.26\end{array}$ \\
\hline $\begin{array}{c}\text { PCMK- } \\
1 / 20\end{array}$ & $\begin{array}{l}28 \\
90\end{array}$ & $\begin{array}{l}3.05 \\
3.76\end{array}$ & $\begin{array}{l}15.33 \\
17.35\end{array}$ & $\begin{array}{l}16.44 \\
17.38\end{array}$ & $\begin{array}{l}2.11 \\
2.02\end{array}$ & $\begin{array}{l}6.65 \\
6.45\end{array}$ & $\begin{array}{l}40.25 \\
40.20\end{array}$ & $\begin{array}{l}2.04 \\
1.04\end{array}$ & $\begin{array}{l}1.61 \\
1.56\end{array}$ & $\begin{array}{c}11.32 \\
9.70\end{array}$ \\
\hline $\begin{array}{c}\text { PCMK- } \\
1 / 40\end{array}$ & $\begin{array}{l}28 \\
90\end{array}$ & $\begin{array}{l}3.36 \\
3.40\end{array}$ & $\begin{array}{l}13.52 \\
15.51\end{array}$ & $\begin{array}{l}15.59 \\
17.21\end{array}$ & $\begin{array}{l}1.96 \\
2.08\end{array}$ & $\begin{array}{l}8.34 \\
8.50\end{array}$ & $\begin{array}{l}30.23 \\
31.34\end{array}$ & $\begin{array}{l}1.90 \\
0.84\end{array}$ & $\begin{array}{l}1.27 \\
1.23\end{array}$ & $\begin{array}{l}22.65 \\
20.13\end{array}$ \\
\hline
\end{tabular}

Se observa un descenso acusado del contenido en $\mathrm{Ca}(\mathrm{OH})_{2}$ en las muestras con un reemplazo del $40 \%$. Sin embargo, los coeficientes de permeabilidad más bajos se obtienen en las mezclas PCMK-1/10 y no en las PCMK$1 / 40$, como cabría esperar debido a la mayor proporción de PC sustituido en esta última. Por lo tanto, la dilución de $\mathrm{PC}$ en las probetas de mortero provocada por la arena MK-1 no es el único factor que afecta al refinado de la estructura porosa y a la permeabilidad del material. Un segundo factor de igual importancia sería la trabajabilidad óptima de los morteros frescos para garantizar una plasticidad adecuada, condición necesaria para lograr una compactación idónea y, en definitiva, una estructura porosa más fina. Se concluye que el porcentaje más adecuado de reemplazo por arena MK-1 en los morteros de PC se encuentra entre el 5 y el $10 \%$.

\section{CONCLUSIONES}

Las conclusiones que pueden deducirse a partir de los resultados de la presente investigación son las siguientes:

a) Se ha demostrado que la arena metacaolínica (MK-1) es un material puzolánico con una puzolanicidad similar a la de un metacaolín puro. La reacción puzolánica se controló determinando el consumo de $\mathrm{Ca}(\mathrm{OH})_{2}$ por parte de la arena en disoluciones saturadas de cal. El consumo de $\mathrm{Ca}(\mathrm{OH})_{2}$ en las mezclas también se confirmó por DRX y ATD-TG.

b) La presencia de la arena MK-1 en las mezclas, debido a su efecto diluyente en la mezcla final y a que su reacción puzolánica es más lenta en el tiempo que la hidratación del cemento, disminuye la intensidad de los procesos reactivos; y como consecuencia la velocidad de desprendimiento de calor y el calor total emitido son menores que en la pasta de referencia.
A steep decline in $\mathrm{Ca}(\mathrm{OH})_{2}$ content was likewise observed in the $40 \%$ replacement samples. The lowest permeability coefficients were found for PCMK-1/10, however, rather than for PCMK-1/40, as would be expected in light of the higher proportion of $P C$ replaced in the latter. The inference is that the dilution of $P C$ by $M K-1$ sand in the mortar specimens is therefore not the only factor affecting pore structure refinement and material permeability. A second factor of equal importance would be optimal workability of fresh mortars to ensure suitable plasticity, a condition necessary for optimal compacting and ultimately a finer pore structure. The optimal replacement ratio by $M K-1$ sand in $P C$ mortars is proposed to lie between 5 and $10 \%$ (wt).

\section{CONCLUSIONS}

The following conclusions are based on the results of this study:

a) Metakaolin sand (MK-1) was shown to be a pozzolanic material with pozzolanicity comparable to pure metakaolin. The pozzolanic reaction was monitored by determining the uptake of $\mathrm{Ca}(\mathrm{OH})_{2}$ by the sand in lime-saturated solutions. $\mathrm{Ca}(\mathrm{OH})_{2}$ uptake by the blends was also confirmed by XRD and DTA-TG.

b) Due to its diluting effect on the final blend and the fact that its pozzolanic reaction is slower than cement hydration, the presence of MK-1 sand in the blends lowered the intensity of the reactions. As a result, the rate of heat release and total heat released were lower than in the reference paste. 
c) De acuerdo con los resultados de los ensayos mecánicos, la arena metacaolínica ha resultado ser una adición puzolánica prometedora. En presencia de superplastificantes, la resistencia a la compresión de los morteros de cemento Portland y arena metacaolínica fue superior a la del mortero de referencia.

d) En comparación con las probetas de referencia, las mezclas y los morteros con contenido de arena MK-1 presentaron una estructura porosa más refinada y una menor permeabilidad. Este refinamiento se acentuó al incrementar el contenido de arena metacaolínica y la edad de curado de las mezclas y morteros.

e) Finalmente, este estudio ha demostrado que la arena metacaolínica (MK-1) puede ser un material válido como adición al cemento, cumpliendo los requisitos de la norma EN 206-1. Asimismo, se ha comprobado que el porcentaje de reemplazo óptimo de arena metacaolínica (MK-1) en un mortero de PC debe estar entre un 5 y un $10 \%$ (en peso); siempre y cuando la consistencia de los mismos sea igual a la del mortero sin adición.

\section{AGRADECIMIENTOS}

Esta investigación ha sido financiada por la Slovak Academy of Sciences (SASci) y el Consejo Superior de Investigaciones Científicas (CSIC) a través del proyecto 2007SK0005 (2008-2009) y el proyecto VEGA $2 / 0053 / 10$. Los autores también quieren agradecer al Ministerio de Ciencia e Innovación su financiación al proyecto BIA2007-61380. Marta Palacios agredece al CSIC la concesión del contrato postdoctoral. c) Further to the mechanical test results, metakaolin sand is a promising pozzolanic addition. Where superplasticizers were used, the compressive strength was higher in the Portland cement-metakaolin sand mortars than in the reference mortar.

d) The blends and mortars containing MK-1 sand had a higher percentage of smaller pores and lower permeability than the reference specimens. This refinement grew more intense with increasing metakaolin sand content and blend and mortar curing time.

e) Finally, this study showed that metakaolin sand (MK1) is apt for use as a European standard EN 206-1compliant cement addition. It also found that the optimal metakaolin sand ( $M K-1)$ replacement ratio in PC mortars must be around 5 to $10 \%$ (wt), providing mortar consistency is the same as in the unadditioned cement mortar.

\section{ACKNOWLEDGEMENTS}

This research was funded by the Slovak Academy of Sciences (SASCi) and the Spanish National Research Council (CSIC) under project 2007 SK0005 (2008-2009) and VEGA Project 2/0053/10. Co-funding was also provided by the Spanish Ministry of Science and Innovation under project BIA2007-61380. M. Palacios worked under a postdoctoral contract awarded by the Spanish National Research Council.

\section{BIBLIOGRAFÍA / BIBLIOGRAPHY}

(1) Kraus, I.: "New approaches to the processing and exploitation of chosen group of silicate of raw materials in Slovakia" (in Slovak language). Proceedings of the EUROSILIKAT 2004 Conference on Innovation and Raising of Competitiveness in the Mining and Processing of Non - Metallic Raw Materials, Lučenec, Slovakia (2004), pp. 36-40.

(2) Kraus, I.; Uhlík, P.; Dubíková, M.; Manfredini, T.; Pavlíková, J.; Šucha, V.; Hanúsková, M.; Honty, M.: "Mineralogical, chemical and technological characterization of kaolin sands". Proceedings of the EUROCLAY International Conference (Book of Abstracts), Modena, Italy, 2003, pp. 160-161.

(3) Krajči, L'.; Janotka, I.; Kraus, I.; Jamnický, P.: "Burnt kaolin sand as pozzolanic material for cement hydration". CERAMICS - Silikáty, vol. 51, no 4 (2007), pp. 217-224.

(4) Janotka, I.; Krajči, L'.; Kuliffayová, M.; Kraus, I.: "Metakaolin sand a prospective substitute for Portland cement". Proceedings of the 4th Mid-European Clay Conference MECC 2008, Zakopane, Poland, September 2008. Abstract is published in Polish Mineralogia Special Papers, vol. 33 (2008), p. 72.

(5) Badiogiannis, E.; Papadakis, V. G.; Chaniotakis, E.; Tsivilis, S.: "Metakaolin as a main cement constituent. Exploitation of poor Greek kaolins". Cement and Concrete Composites, vol. 27, no 2 (2005), pp. 197-203. doi:10.1016/j.cemconcomp.2004.02.007

(6) Frías, M.; Cabrera, J.: "Pore size distribution and degree of hydration of metakaolin - cement pastes". Cem. Concr. Res., vol. 30, no 4 (2004), pp. 561-569. doi:10.1016/S0008-8846(00)00203-9

(7) Frías, M.; Sánchez de Rojas, M. I.: "Influence of metastable hydrated phases on the pore size distribution and degree of hydration of MK - blended cements cured at $60{ }^{\circ} \mathrm{C}^{\prime \prime}$. Cem. Concr. Res., vol. 35, no 7 (2005), pp. 1292-1298. doi:10.1016/j.cemconres.2004.10.038

(8) Torres, J.; Mejía de Gutiérrez, R.; Puertas, F.: "Effect of kaolin treatment temperature on mortar chloride permeability". Mater. Construcc., vol. 57, no 285 (2007), pp. 61-69. 
(9) Frías, M.; Sánchez de Rojas, M. I.; Rodríguez, O.; García Jiménez, R.; Vigil de la Villa, R.: "Characterization of calcined paper sludge as an environmentally friendly source of metakaolin for manufacture of cementitious materials". Advances in Cement Research, vol. 20, no 1 (2008), pp. 23-30. doi:10.1680/adcr.2008.20.1.23

(10) Vegas, I.; Frías, M.; Urreta, J.; San José, C. T.: "Obtaining a pozzolanic addition from the controlled calcination of paper mill sludge. Performance in cement matrices". Mater. Construcc., vol. 56, n 283 (2006), pp. 49-60.

(11) Rodríguez, O.: "Valorizacion de un residuo industrial procedente de la industria papelera como material puzolánico", tesis doctoral 2008, Universidad Autónoma de Madrid.

(12) Frías, M.; Sánchez de Rojas, M. I.; Cabrera, J.: "The effect that the pozzolanic reaction of metakaolin has on the heat evolution in metakaolin - cement mortars". Cem. Concr. Res., vol. 30, no 2 (2000), pp. 209-216. doi:10.1016/S0008-8846(99)00231-8

(13) Bágel', L'.; Živica, V.: "Relationship between pore structure and permeability of hardened cement mortars". Cement and Concrete Research, vol. 27, no 8 (1977), pp. 1225-1235.

(14) Janotka, I.; Bágel', L'.: "Pore structures, permeabilities and compressive strengths of concrete at temperatures up to 800 oC". $A C I$ Materials Journal, vol. 99, n० 2 (2002), pp. 196-200.

(15) Mojumdar, S. C.; Sain, M.; Prasad, R. C.; Sun, L.; Venart, J. E. S.: "Selected thermoanalytical methods and their applications from medicine to construction: Part 1". Journal of Thermal Analysis and Calorimetry, vol. 90, no 3 (2007), pp. 653-662. doi:10.1007/s10973007-8518-5 